\title{
The antecedents and outcomes of work-family enrichment amongst female workers
}

\begin{tabular}{|c|c|}
\hline \multicolumn{2}{|c|}{$\begin{array}{l}\text { Authors: } \\
\text { Esandre Marais }{ }^{1} \\
\text { Marissa de Klerk }^{1} \\
\text { Jan Alewyn Nel } \\
\text { Leon de Beer }\end{array}$} \\
\hline $\begin{array}{l}\text { Affiliations: } \\
{ }^{1} \text { School of Hun } \\
\text { Sciences, Nort } \\
\text { University, Pot } \\
\text { Campus, Soutr }\end{array}$ & $\begin{array}{l}\text { nan Resource } \\
\text { h-West } \\
\text { chefstroom } \\
\text { Africa }\end{array}$ \\
\hline $\begin{array}{l}{ }^{2} \text { WorkWell Res } \\
\text { North-West Ur } \\
\text { Potchefstroom } \\
\text { South Africa }\end{array}$ & $\begin{array}{l}\text { search Unit, } \\
\text { niversity, } \\
\text { Campus, }\end{array}$ \\
\hline $\begin{array}{l}\text { Corresponden } \\
\text { Leon de Beer }\end{array}$ & ce to: \\
\hline $\begin{array}{l}\text { Email: } \\
\text { debeer.leon@ }\end{array}$ & nwu.ac.za \\
\hline $\begin{array}{l}\text { Postal address } \\
\text { Private Bag X6 } \\
\text { North-West Ur } \\
\text { Potchefstroom } \\
\text { South Africa }\end{array}$ & $\begin{array}{l}\text { 001, } \\
\text { niversity, } \\
2520\end{array}$ \\
\hline $\begin{array}{l}\text { Dates: } \\
\text { Received: } 25 \mathrm{~N} \\
\text { Accepted: } 22 \mathrm{~J} \\
\text { Published: } 25\end{array}$ & $\begin{array}{l}\text { Jov. } 2013 \\
\text { uly } 2014 \\
\text { Nov. } 2014\end{array}$ \\
\hline $\begin{array}{l}\text { How to cite th } \\
\text { Marais, E., De } \\
\text { J.A., \& De Bee } \\
\text { antecedents a } \\
\text { of work-family } \\
\text { amongst fema } \\
\text { SA Journal of I } \\
\text { Psychology/SA } \\
\text { Bedryfsielkuno } \\
\text { \#1186, } 14 \text { pag } \\
\text { http://dx.doi.o } \\
\text { sajip.v40i1.118 }\end{array}$ & $\begin{array}{l}\text { is article: } \\
\text { Klerk, M., Nel, } \\
\text { r, L. (2014). The } \\
\text { nd outcomes } \\
\text { enrichment } \\
\text { le workers. } \\
\text { ndustrial } \\
\text { Tydskrif vir } \\
\text { ee, } 40(1) \text {, Art. } \\
\text { es. } \\
\text { rg/10.4102/ } \\
36\end{array}$ \\
\hline $\begin{array}{l}\text { Copyright: } \\
\text { (C) 2014. The A } \\
\text { Licensee: AOS } \\
\text { OpenJournals. } \\
\text { is licensed und } \\
\text { Creative Comn } \\
\text { Attribution Lic }\end{array}$ & $\begin{array}{l}\text { IS } \\
\text { IS } \\
\text { This work. } \\
\text { der the } \\
\text { nons } \\
\text { ense. }\end{array}$ \\
\hline Read online: & $\begin{array}{l}\text { Scan this QR } \\
\text { code with your } \\
\text { smart phone or } \\
\text { mobile device } \\
\text { to read online. }\end{array}$ \\
\hline
\end{tabular}

Orientation: Women are involved in both a work and a family domain. Work-family enrichment is a concept that describes how these domains can enrich each other through the transfer of resources from one domain to the other.

Research purpose: The objective was to determine the relationship between work resources, home resources, work engagement, family engagement and work-family enrichment. The aim was also to test two models representing work-to-family and family-to-work enrichment as mediators.

Motivation for the study: By investigating work-family enrichment, as a new research concept, and its antecedents and outcomes, this study will add to the positive side of the work-family interface literature and provide information to organisations.

Research design, approach and method: A cross-sectional survey design was used in this study with a sample of female workers $(N=420)$ in South Africa. Polychoric correlations, fit indices, structural equation modelling and testing mediation were used to analyse the data. Omegas and alpha coefficients were employed to determine the reliability.

Main findings: A positive relationship between work-family enrichment and its antecedents and outcomes was found. Furthermore, work-family enrichment (W-FE) mediated (large effect) the relationship between work resources and work engagement and family-work enrichment mediated (small effect) the relationship between home resources and family engagement.

Practical/managerial implications: The results provide more insight and understanding to organisations and female workers on the benefits of being involved in both the domain of work life and the domain of family life.

Contribution/value-add: The study contributes to the limited research undertaken on workfamily enrichment within the South African context. The present study also contributes to the literature on the use of the newly developed MACE Work-Family Enrichment Instrument.

\section{Introduction}

Previous studies on the phenomenon of work life interface mostly focus on female workers (Rantanen, Kinnunen, Mauno \& Tillemann, 2011), and also on the negative effects of multiple roles of women with little regard to the enhancing effects (Barnett \& Baruch, 1985; Tiedje et al., 1990). Even today, research pertaining to the work-family interface mainly consists of dedicated studies on the negative impact multiple roles can generate in the family life and work life of employees and the effects thereof on their health (Gareis, Barnett, Ertel \& Berkman, 2009; Koekemoer, Mostert \& Rothmann, 2010). However, in all of these studies, women and men were not studied separately; family roles were more generalised to parent and spouse (therefore, irrespective of gender). Apart from this, a new tendency in the research of work-family interface emerged. Researchers (Baral \& Bhargava, 2011; Boixados, Hernandez, Guillamon \& Pousada, 2010; De Klerk, Nel, Hill \& Koekemoer, 2013) now suggest that an employee's work life and family life can provide reciprocal enrichment through the resources and rewards inherent in each role. These studies fall within the premise of the role enhancement theory (Marks, 1977). The role enhancement theory is a beneficial element for employees to use the experiences of one role in the improvement of another role (Barnett \& Hyde, 2001). Therefore, when employees fulfil multiple roles, this can provide more opportunities and resources for them to succeed and to feel good about themselves and this condition in turn can result in employees being empowered and having more control over their lives (Baral \& Bhargava, 2011; Boixados et al., 2010; Ruderman, Ohlott, Panzer \& King, 2002). The aforementioned is known as work-family enrichment and falls within the hypothesis of the role enhancement perspective (Rantanen et al., 2011). Consequently, it seems prudent to gain knowledge on the complexity of work-family dynamics and to assess what positive influences these may generate. 
Assessing most recent literature relating to relevant antecedents for work-family enrichment (Cheng, Mauno \& Lee, 2013; Kacmar, Crawford, Carlson, Ferguson \& Whitten, 2014; Siu et al., 2010; Tang, Siu \& Cheung, 2014) it seems that mainly home resources and work resources are used to evaluate the effect on workers' work-family enrichment. According to Siu et al. (2010) and Kacmar et al. (2014), certain resources gained from work life had a positive effect on the work-to-family experiences of employees, whilst certain resources gained from a person's home life had a positive effect on the family-to-work experiences of an employee. Apart from the aforementioned, these experiences may lead to positive outcomes for employees. Primarily, various studies tested work-family enrichment as a mediator for home resources and work resources (as antecedents) with engagement (as a consequence) (Cheng et al., 2013; Jaga \& Bagraim, 2011; Nicklin \& McNall, 2013; Siu et al., 2010; Tang et al., 2014). More specifically, these studies have shown that work engagement is an outcome of work-to-family enrichment and that family engagement is an outcome of family-to-work enrichment. In these studies support (from home and work) and job control (autonomy) were assessed as antecedents. However, as indicated in the previous paragraph as well, no distinction was made in the differences between men and women in the aforementioned studies. These studies mostly based their research on an overall worker corps or within a specific industry. This raises the question, what will workfamily enrichment look like for female workers in the current work context in South Africa?

From reviewing the censuses undertaken in 2001 and 2011, it seems that the number of women entering the labour market showed an increase from $31.5 \%$ in 2001 to $34.6 \%$ in 2011, whilst a decrease was evident of unemployed and economically inactive females (Statistics South Africa, 2001; 2011). Women are becoming even more prominent in the work context; several reasons can be provided for this upsurge (i.e. more rigorous implementation of the Employment Equity Act, global economic changes) (Fernandez, 2013; McLellan \& Uys, 2009; Van den Berg \& Van Zyl, 2008). As mentioned earlier, women have always formed part of the labour market and been included in work-family interface studies (Barnett \& Baruch, 1985; Tiedje et al., 1990), but more recent studies are lacking, especially concerning work-family enrichment pertaining to female workers. According to Franks, Schurink and Fourie (2006), even today women are still socialised to perform their traditional home roles (being a mother, wife and homemaker), but how this benefits the female worker in both her home life and work life is not known (Frone, 2003; Gareis et al., 2009). From the above arguments, it was important for the authors to determine whether workfamily enrichment can be a mediator for work resources, home resources, work engagement and family engagement, specifically amongst female workers.

\section{Research purpose and objectives}

In light of the above discussion, the purpose of the present study was twofold. Firstly, the researchers aimed to assess whether a relationship exists between the antecedents (work resources and home resources), outcomes (work engagement and family engagement) and work-family enrichment amongst female workers. Secondly, the researchers sought to establish the mediating role of work-family enrichment between work resources, home resources, work engagement and family engagement of female workers. The study contributes to the limited research undertaken on work-family enrichment within the South African context. The present study also contributes to the work-family enrichment literature by using the newly developed MACE Work-Family Enrichment Instrument. Furthermore, it also contributes to investigating antecedents and outcomes related to work-family enrichment for South African female workers.

\section{Literature review and hypotheses A theoretical framework for work-family enrichment}

Researchers have recently paid increasing attention to the positive synergies between the work and family domains. This was done under a variety of constructs such as positive spillover (Hanson, Hammer \& Colton, 2006), facilitation (Frone, 2003; Wayne, Grzywacz, Carlson \& Kacmar, 2007), enhancement (Ruderman et al., 2002) and enrichment (Carlson, Kacmar, Wayne \& Grzywacz, 2006; Greenhaus \& Powell, 2006). According to Carlson et al. (2006), as well as Hanson et al. (2006), such constructs can all be categorised under the heading of work-family enrichment.

Both the concepts work-family enrichment and work-family positive spillover incorporate the notion that experiences or resources in one domain (work or family) can be transferred (spilled over) to the other domain (family or work) (see Edwards \& Rothbard, 2000; Greenhaus \& Powell, 2006; Grzywacz \& Marks, 2000; Hanson et al., 2006). Work-family enrichment, however, requires more than the transfer (i.e. spillover) of experiences or resources from one domain to the other. The transfer should also be applied successfully in a way that leads to improved performance or affect for the individual (Powell \& Greenhaus, 2004).

On the other hand, work-family enrichment and work-family facilitation are more closely linked, since the facilitation focuses on the positive outcomes of the work-family interface. However, enrichment entails more than improvement in the role-performance of individuals' lives (Wayne et al., 2007); it focuses on the individual and on the resources that assist improvement in their work or family life, whilst facilitation focuses on the system as such (i.e. work or family). Facilitation on the other hand aims at improving the entire system's functioning for the individual (Wayne et al., 2007). By focusing more on the individual level, researchers may get a clearer picture of the person's experiences and resources that may spill over across domains, leading to enhanced functioning in both domains and therefore a better quality of life. Therefore Greenhaus and Powell (2006) suggest that work-family enrichment best captures the mechanism of the positive work-family interface and define it as 'the extent to 
which experiences in one role improve the quality of life in the other role' (Greenhaus \& Powell, 2006, p. 72).

Greenhaus and Powell's (2006) comprehensive theoretical framework of work-family enrichment draws upon previous work by Sieber (1974) and Marks (1977). In Sieber's (1974) theory of role accumulation, people are thought to experience work-family enrichment because various rewards (e.g. role privileges, status enhancement and personality enrichment) occur when individuals participate in multiple roles. Marks's expansionist approach argues that multiple roles may be performed without energy loss or may even create energy for use in that role or others. Thus, participating in a work role may generate resources that can energise an employee's family role or vice versa. Work-family enrichment therefore investigates how involvement and resources (such as skills and perspectives, flexibility, psychological and physical resources, social-capital resources and material resources) gained in one domain (work or family) can contribute to and improve experiences in the other domain (work or family). Greenhaus and Powell (2006) point out that workfamily enrichment is also considered to be bi-directional. This means that enrichment occurs in both directions. Furthermore, work-family enrichment can occur in two modes. Firstly, such enrichment takes place when resources gained from Role-A (the work or family life) directly improve performance in Role-B (the work or family life): the instrumental path. Secondly, this enrichment can occur indirectly through the resources' influence on positive affect: the affective path (Greenhaus \& Powell, 2006).

Carlson et al. (2006) were the first to develop a measuring instrument based on Greenhaus and Powell's (2006) theoretical model to assess work-family enrichment. However, the scale of Carlson et al. fails to address all of the necessary resources (skills and perspectives, psychological and physical, flexibility, social-capital and material) as proposed by Greenhaus and Powell's work-family enrichment theoretical model. In an attempt to address this issue and further measurement issues, as well as matters on theory building related to the positive side of the workfamily interface, De Klerk et al. (2013) developed the MACE Work-Family Enrichment Instrument. This instrument was also based on the work-family enrichment theoretical model proposed by Greenhaus and Powell.

This new instrument includes more resources (such as perspectives, affect, socio-capital and time-management) than Carlson et al.'s (2006) measure and measures the enrichment between work and family in both directions. In other words, it measures work-to-family enrichment (WFE) and family-to-work enrichment (F-WE). The instrument consists of sub-dimensions (e.g. work-family perspectives, family-work perspectives, etc.) for each direction. In each case these sub-dimensions form part of a reciprocal process that improves the individuals' quality in the work or family role (De Klerk et al., 2013). For purposes of this study the MACE Work-Family Enrichment Instrument was thus used, seeing that it provides more resources for an assessment.

\section{Work-family enrichment in the South African context}

Although there are quite a few studies on work-family enrichment (De Klerk et al., 2013; Jaga \& Bagraim, 2011; Jaga, Bagraim \& Williams, 2013), studies on work-family enrichment in the South African context, specifically, are rare in the literature. Examining work-family enrichment in South Africa is relevant because South Africa is a multicultural society faced with unique and different circumstances. These different circumstances may exist due to different cultural backgrounds, values, norms and ethnicities amongst various South African groups (Lewis, 1997). Because of these differences, various cultural groups may experience and influence the enrichment between their work and family lives differently from one another and from other countries. Furthermore, it is also evident that South Africa experienced various societal influences, changes and organisational structures (such as increased domestic and international competition, restructuring, downsizing, outsourcing, cuts in government funding, changes in management style and structure, lay-offs, mergers, rapidly changing technology, as well as demands for higher-quality products and services), which also have a direct impact on the interaction between employees' work and family lives (Gillespie, Walsh, Winefield, Dua \& Stough, 2001). An enriching interaction between employees' work and family lives is of paramount importance to the economic viability of institutions and to the welfare of families (Barnett, 1998). Hence, exploring the work-family enrichment dimension in South Africa is a sensible effort.

\section{The relation between work resources and work-to- family enrichment}

Work resources are those physical, social, psychological or organisational aspects that can be functional in achieving work goals and simultaneously stimulate personal growth, development and learning (Hakanen, Bakker \& Schaufeli, 2006). In this sense work resources may include aspects such as work support (supervisor and social), work-related developmental possibilities and work autonomy (Mostert, 2012). Worksupport is located at an interpersonal level, whereas work-related developmental possibilities are located at a macro, organisational level and work autonomy at the level of the task (Demerouti \& Bakker, 2011). Conservation of resource (COR) theory (Hobfoll, 2002) can be used to better understand how work resources (such as work support, work-related development possibilities and work autonomy) may relate to managing multiple role membership. COR theory presents that individuals seek to obtain, retain and protect resources. According to COR theory, people with more resources in their lives are more capable of solving problems and are less likely to be affected by resource drain. Work resources are a positive predictor of work-to-family enrichment and this may indicate that when adequate work resources are available to an individual, as a consequence they may experience an enriching situation at home (Hakanen, Peeters \& Perhoniemi, 2011). Therefore, it may be assumed that female workers who have more resources available at work are more capable of solving problems in their home domain, which in turn 
enriches their work domain. A positive relationship has also been found between work-to-family enrichment and work support (Baral \& Bhargava, 2011; Beutell \& Wittig-Berman, 2008; Hill, 2005; Karatepe \& Beketshi, 2008; Nicklin \& McNall, 2013; Wadsworth \& Owens, 2007). More specifically, Baral and Bhargava (2011) have only found a positive relationship between supervisor support and work-to-family enrichment. The finding is consistent with other research as well (Beutell \& Wittig-Berman, 2008; Hill, 2005; Karatepe \& Beketshi, 2008; Wadsworth \& Owens, 2007). Nicklin and McNall (2013) also found that supervisor support is related to work-to-family enrichment. This may indicate that when support at work is available it may help the individual to integrate work and family responsibilities and such a condition may provide the individual with psychological resources such as confidence to deal with both work and family duties (Baral \& Bhargava, 2011; Winfield \& Rushing, 2005). It has also been found that workers who experience work-to-family enrichment also experience increased work resources such as autonomy and work-related developmental possibilities (Innstrand, Langballe \& Falkum, 2010; Geurts et al., 2005; Voydanoff, 2004). Demerouti, Geurts and Kompier (2004) have also found a positive relationship between work resources, such as autonomy and social support, and work-family facilitation. Hence, it is hypothesised that:

Hypothesis 1a: There is a positive relationship between work resources and work-to-family enrichment amongst female workers.

\section{The relationship between home resources and family-to- work enrichment}

Home resources are those aspects of the home situation that help to reduce demands from home and foster development, growth and well-being in the home domain (Hakanen et al., 2011). As in the case of work resources, home resources may include variables such as home support, home-related developmental possibilities and home autonomy. Home support can refer to instrumental, informational, emotional and appraisal support from significant others (Ten Brummelhuis \& Bakker, 2012). Home-related developmental possibilities can be seen as opportunities for self-growth in the home domain (e.g. developing your talents during your free time) (Demerouti, Bakker \& Voydanoff, 2010). Home autonomy implies that the individual is able to decide how and when home tasks are performed (Ten Brummelhuis \& Bakker, 2012). Hakanen et al. (2011) found that familyto-work enrichment positively predicted home resources. This indicates that when an individual feels the roles in their private life are enriching and therefore improving the quality of the work role, this condition in turn may improve satisfaction in the home life and provide increased positive perceptions of support from family and friends (Hakanen et al., 2011). Demerouti (2012) maintains that individuals who transfer energy and motivation gained from the work domain to the family domain generate home resources such as social support, autonomy and developmental possibilities. Several studies also found a positive relationship between home support and family-to-work enrichment (Aryee, Srinivas \& Tan, 2005; Baral \& Bhargava, 2011; Grzywacz \&
Marks, 2000; Karatepe \& Bekteshi, 2008). This means that support from home can help the individual to invest more energy and time at work and to partake in work activities without any concerns or worries (Baral \& Bhargava, 2011). Thus, in support of COR theory, women with more resources from the family may be more capable of solving problems at work and be less affected by resource drain, thus enriching the family domain. Research has shown that a resource such as family support seems to be especially important in motivating employees to work harder at their jobs (Tang et al., 2014). COR theory suggests that individuals employ resources that they possess or call on resources that are available to them from their environment; therefore, it can be suggested that resources generated in the family role can improve work role-performance (e.g. Demerouti et al., 2010; Graves, Ohlott \& Ruderman, 2007; Greenhaus \& Powell, 2006; Hunter, Perry, Carlson \& Smith, 2010; Weer, Greenhaus \& Linnehan, 2010). Therefore, it is hypothesised that:

Hypothesis $1 \mathrm{~b}$ : There is a positive relationship between home resources and family-to-work enrichment amongst female workers.

\section{The relationship between work-to-family enrichment and work engagement}

Work engagement can be defined as a positive, energetic, fulfilling, work-related state of mind in which employees are dedicated to excellent performance at work and are confident of their effectiveness; this state of mind is characterised by vigour, absorption and dedication (Bezuidenhout \& Cilliers, 2010; Schaufeli, Salanova, González-Romá \& Bakker, 2002; Schutte, Toppinen, Kalimo \& Schaufeli, 2000). Vigour refers to high levels of energy and resilience and the willingness to invest in one's job and other activities and not being exhausted easily; absorption is characterised by being fully happy to be surrounded by one's work and to forget about time and everything else; dedication means having a strong involvement in one's work accompanied by feelings of enthusiasm, pride, loyalty, significance and inspiration (Schaufeli et al., 2002). Previous studies (e.g. Balmforth \& Gardner, 2006; Gordon, Whelan-Berry \& Hamilton, 2007; Van Steenbergen, Ellemers \& Mooijaart, 2007) examined the outcomes of work-to-family enrichment and found that work-to-family enrichment was more strongly related to work outcomes (McNall, Masuda \& Nicklin, 2010).

Research that has been done on the relationship between work-family enrichment and work engagement found that work engagement mediates the relation between supervisor support and job autonomy (all of which form part of work resources) and work-to-family enrichment (Siu et al., 2010). This suggests that support from supervisors may help individuals' work-family enrichment by enhancing their experience of their work role. Another indication is that individuals who perceive more work autonomy may experience higher work-family enrichment; thus, autonomy can provide employees with skill discretion and work creativity, which foster improved engagement in their work (Siu et al., 2010). Having vigour, absorption and dedication 
is also likely to have a positive impact on the atmosphere at home and may therefore result in work-to-family enrichment (Siu et al., 2010). According to COR theory (Hobfoll, 1989), individuals tend to persevere, protect and expand their resources (e.g. objects, personal characteristics, conditions or energies) to reduce work disengagement. COR theory also suggests that employees invest resources in ways that will maximise their returns and in a manner that is most fitting with the specific resource invested; thus, work resources are often reinvested in the workplace (Hobfoll, 2001). Therefore, those with excess work resources (e.g. those with high engagement) are likely to reinvest those resources back into work (Halbesleben \& Wheeler, 2008; Hobfoll, 2001) by doing their jobs exceptionally well (Saks, 2006; Salanova, Agut \& Peiró, 2005). When one uses COR theory to understand the relationship between work-family enrichment and work engagement, it emphasises the dynamism of resources deployment. This is because one role provides resources that assist the person to manage the responsibilities of the other role and improve the quality of the receiving role. Based on COR theory and previous findings of existing relations between work engagement and work-to-family enrichment, it is hypothesised that:

Hypothesis 1c: There is a positive relationship between work engagement and work-to-family enrichment amongst female workers.

\section{The relationship between family-to-work enrichment and family engagement}

Family engagement can be seen as the flipside of work engagement and can therefore be defined as the condition in which employees feel positive and energetic towards their family, get a sense of fulfilment from their family and can also be characterised by vigour, absorption and dedication (Bezuidenhout \& Cilliers, 2010; Schaufeli et al., 2002; Schutte et al., 2000). With family engagement viewed as the flipside of work engagement, family vigour can be understood as high levels of energy and resilience and the willingness to invest in one's family or other activities and not become easily exhausted; family absorption can be characterised as being fully content being surrounded by one's family and forgetting about time and everything else; family dedication implies a strong involvement in one's family accompanied by feelings of enthusiasm, pride, loyalty, significance and inspiration (Schaufeli et al., 2002). Previous studies (e.g. Balmforth \& Gardner, 2006; Gordon et al., 2007; Van Steenbergen et al., 2007) examined the outcomes of family-to-work enrichment and found that family-to-work enrichment was more strongly related to family outcomes (McNall et al., 2010). A study done by Rothbard (2001) on the relationship between family engagement and enhanced work performance of women suggests that women who build a positive family environment also enrich their work domain (Halbesleben, Harvey \& Bolino, 2009). Furthermore, when resources are generated through family experiences it can lead to family engagement (Graves et al., 2007). Higher engagement can lead to higher family enrichment also through the generation of increased resources (Rothbard, 2001).
These findings can be elucidated by means of COR theory (Hobfoll, 1989). According to COR theory, individuals attempt to obtain, retain and protect resources (Hobfoll, 2002). These resources are defined as those conditions (such as marital status), personal characteristics (such as selfefficacy) and energies (such as time) that are valued by the individual. Individuals with greater resources are less likely to be affected by the drain of resources that accompany several role demands. Therefore it can be assumed that individuals are better able to cope with stress-related variables that negatively influence their well-being (McNall et al., 2010; Odle-Dusseau, Britt \& Greene-Shortridge, 2012). When one uses COR theory to understand the relationship between family-work enrichment and family engagement, it emphasises the vitality of resources deployment. This is because one role provides resources that assist the person to manage the responsibilities of the other role and improve the quality of the receiving role, thereby enhancing the wellbeing of an individual. Based on COR theory and previous findings of existing relationships between family engagement and family-to-work enrichment, it is hypothesised that:

Hypothesis 1d: There is a positive relationship between family engagement and family-to-work enrichment amongst female workers.

\section{The mediating role of work-family enrichment and family- work enrichment}

The empirical evidence obtained on the potential mediating role of work-family enrichment in the link between antecedents (such as work resources and home resources) and outcomes (such as work engagement and family engagement) has mostly been indirect. Firstly, it has been found that work resources (such as work support) and home resources (such as home support) are positively related to some measure on work-family enrichment (Aryee et al., 2005; Baral \& Bhargava, 2011; Beutell \& Wittig-Berman, 2008; Grzywacz \& Marks, 2000; Hill, 2005; Karatepe \& Beketshi, 2008; Nicklin \& McNall, 2013; Wadsworth \& Owens, 2007). Secondly, there is evidence to show that work-family enrichment is linked to various indicators of outcomes (such as engagement) (Rothbard, 2001; Siu et al., 2010).

These findings together with aforementioned support for the direct relationships between antecedents and outcomes may point towards the possibility of mediation. Only a few studies measured the mediating role of work-family enrichment for other variables. For example McNall, Masuda and Nicklin (2010) measured the mediating role of workfamily enrichment between flexible work arrangements, job satisfaction and turnover intention. Furthermore, Baral and Bhargava (2010) measured the mediating effect of workfamily enrichment between organisational interventions for work-family balance and job outcomes. Therefore, it seems necessary to further investigate the mediating effect of workfamily enrichment between antecedents (such as work and home resources) and outcomes (such as work and family engagement). The mediation model was grounded on COR theory (Hobfoll, 1989), the model of work-family enrichment (Greenhaus \& Powell, 2006) and previous research findings. 
COR theory proposes that to reduce stress, individuals tend to acquire and maintain resources, which can result in a positive gains spiral (Hobfoll, 2001). Resources include objects, personal characteristics, conditions, energies and social support (Hobfoll, 2002). This study used COR theory to understand the relationship between work resources, home resources, work engagement and family engagement. For example, work support, work developmental possibilities and work autonomy are resources and resources gained may reduce the experience of stress and its negative consequences, such as work disengagement. Resource generation is essential to the enrichment process (Friedman \& Greenhaus, 2000). Greenhaus and Powell's (2006) model suggests that there are five kinds of resources (i.e. skills and perspectives, psychological and physical resources, social-capital resources, flexibility and material resources) that may be acquired in a role to improve performance in the other role. Going beyond the enrichment process, COR theory (Hobfoll, 1989) is used to further understand the relationship between enrichment and outcomes such as work engagement and family engagement. For example, when female workers perceive their organisations to be helpful in managing their work and family roles, the employees should be able to generate more resources from their work and family roles leading to more engagement within their work and family lives. Therefore, based on COR theory, the model of work-family enrichment and previous research findings, it is predicted that changes in the level of resources could lead to changes in the level of enrichment within the work and the family domain, which in turn could lead to changes in the level of engagement amongst female workers. Hence, it is hypothesised that:

Hypothesis 2a: Work-family enrichment mediates the relationship between work resources and work engagement as an outcome amongst female workers.

Hypothesis 2b: Family-work enrichment mediates the relationship between home resources and family engagement as an outcome amongst female workers.

\section{Research design}

The research approach and the research method are discussed below.

\section{Research approach}

The study was quantitative in nature and a cross-sectional survey design was used to reach the research objectives. With a cross-sectional design several groups of people are examined at one point in time; the reason the researcher opted for the cross-sectional survey design was that it is easier and less expensive to conduct (De Vos, Strydom, Fouché \& Delport, 2011).

\section{Research method \\ Research participants}

As seen in Table 1, only 420 questionnaires were returned, although 450 were distributed. A combined purposive and convenience non-probability sampling method was used. Inclusive criteria were applied such that the women were required to be employed full time and have a family life. Characteristics of the sample are provided in Table 1.

All the participants were female, of which $81.7 \%$ were white participants, $11.9 \%$ were African participants and $5.50 \%$ were mixed-race participants. In total, $84 \%$ of the participants spoke Western Germanic languages (Afrikaans or English) and $10.2 \%$ spoke African languages. In terms of age, the highest percentage $(33.8 \%)$ of the population was between the ages of 24 and 33 years, followed by participants between 34 and 43 years of age (25.7\%). With respect to qualification, the highest percentage (30.2\%) of the participants had a Grade 12 , followed by those with a postgraduate degree (27.9\%).

\section{Measuring instruments}

The following measuring instruments were used in the empirical study.

Biographical characteristics: A biographical questionnaire was provided to gather information on the participants' gender, age, ethnicity, language and highest qualification.

Work resources: Three work resources were measured, namely support, work-related developmental possibilities and autonomy. These three items of work resources were rated on a four-point Likert scale ranging from 0 (never) to 3 (always). Work support was measured by the scale developed by Bakker, Demerouti and Verbeke (2004). This entailed three items, for example 'How often does it happen that you can count on your colleagues when you have difficulty in your work?' Work-related developmental possibilities were assessed by three items that were conceptually mirrored from

TABLE 1: Characteristics of the participants $(N=420)$.

\begin{tabular}{|c|c|c|c|}
\hline Item & Category & $f$ & $\%$ \\
\hline Gender & Female & 420 & 100.00 \\
\hline \multirow[t]{4}{*}{ Ethnicity } & White & 343 & 81.70 \\
\hline & African & 50 & 11.90 \\
\hline & Mixed-race & 23 & 5.50 \\
\hline & Indian & 4 & 1.00 \\
\hline \multirow[t]{7}{*}{ Age } & $18-23$ years & 26 & 6.20 \\
\hline & $24-33$ years & 142 & 33.80 \\
\hline & $34-43$ years & 108 & 25.70 \\
\hline & $44-53$ years & 87 & 20.70 \\
\hline & $55-63$ years & 50 & 11.90 \\
\hline & $64-73$ years & 4 & 1.00 \\
\hline & Missing values & 3 & 0.70 \\
\hline \multirow[t]{3}{*}{ Language } & Western Germanic & 353 & 84.00 \\
\hline & African & 43 & 10.20 \\
\hline & Missing values & 24 & 5.70 \\
\hline \multirow[t]{7}{*}{ Qualification } & Lower than Grade 12 & 15 & 3.50 \\
\hline & Grade 12 & 127 & 30.20 \\
\hline & Post-matric diploma (Tech) & 65 & 15.50 \\
\hline & Undergraduate degree & 80 & 19.00 \\
\hline & Postgraduate degree & 117 & 27.90 \\
\hline & Other & 8 & 1.90 \\
\hline & Missing values & 8 & 1.90 \\
\hline
\end{tabular}

$f$, frequency. 
existing scales of home-related developmental possibilities developed by Demerouti et al. (2010). An example item is: 'How often does it happen that at your work you have the opportunity to develop your strong points?' Work autonomy was measured with the scale developed by Bakker et al. (2004). This consisted of three items, for example 'How often does it happen that you have a say in decisions that affect your work?'

Home resources: The questions for home resources were developed by Demerouti et al. (2010) and conceptually mirror existing scales of work resources; several researchers have used a work-related measure successfully as a model to construct a symmetrical home-related measure (Frone \& Rice, 1987; Frone, Russell \& Cooper, 1992; Parasuraman, Purohit, Godshalk \& Beutell, 1996). All these items of home resources were rated on a four-point Likert scale ranging from 0 (never) to 3 (always). Home support was measured in terms of four items, including 'How often does it happen that your partner or family members show that they value you for the work you do at home?' Home-related developmental possibilities were assessed by three items, including 'How often does it happen that in your free time you have the opportunity to develop yourself?' Home autonomy was assessed with four items, including 'How often does it happen that you decide for yourself how you spend your leisure time?'

The MACE Work-Family Enrichment Instrument: This was measured using 30 items from the MACE Work-Family Enrichment Instrument developed by De Klerk et al. (2013). Respondents indicated their level of agreement to each statement (e.g. 'My family life is improved by my work showing me different viewpoints'), on a four-point scale: 1 (disagree), 2 (neither agree nor disagree), 3 (agree) and 4 (strongly agree).

Work engagement: This was measured using the 11 items from the Utrecht Work Engagement Scale (UWES) developed by Schaufeli et al. (2002). Respondents indicated their level of agreement to each statement (e.g. 'At my work, I feel bursting with energy') on a seven-point frequency rating scale ranging from 1 (never) to 7 (every day).

Family engagement: This was measured using an adapted version of 13 items from the UWES scale. Respondents indicated their level of agreement to each statement (e.g. 'I am enthusiastic about spending time with my family') on a seven-point frequency rating scale varying from 1 (never) to 7 (every day).

\section{Research procedure and ethical considerations}

The proposed research was presented to the Research Committee of North-West University. After ethical clearance was obtained from the university's Ethics Committee, a test booklet was compiled consisting of the relevant measuring instruments. The researcher approached various industries (such as education, manufacturing, etc.) within the South African context. Only women from various industries willing and able to participate in the study were asked to complete the English test booklet. A letter requesting participation and consent from the female participants was included in the test booklet, as well as an explanation of ethical aspects and a motivation concerning the importance of the research.

Furthermore, in the letter of the test booklet, female participants were assured of the anonymity and confidentiality with which the information would be dealt. The booklets were distributed personally to the female employees from the various participating organisations. Female participants were given two to three weeks to complete the research booklets before the researcher collected them.

\section{Statistical analysis}

The statistical analysis was carried out with structural equation modelling (SEM) methods as implemented by Mplus 7.11 (Muthén \& Muthén, 2013). The reason for choosing Mplus is due to its unique ability to specify continuous and latent variables in analysis (De Beer, Pienaar \& Rothmann, 2013; Muthén \& Muthén, 2013). In order to test the hypotheses, both a measurement and a structural model were investigated. The default estimator for models that contain observed categorical data in Mplus is the mean and variance-adjusted weight least squares method (WLSMV) (Muthén \& Muthén, 2013).

In the measurement model, confirmatory factor analysis was applied to test the factorial validity of the measuring instruments. The input type was the covariance matrix. Furthermore, a correlation matrix from Mplus for the latent variables was also generated in the analysis for reporting. Due to the high correlations between individual latent factors, second-order latent variables were created, which amounts to the shared variance amongst individual latent indicators for the global construct (see Table 2). This was done to offset any potential multicollinearity or suppression effects in the model due to the high correlation coefficients.

Omega coefficients were used to determine the reliability of the constructs that were measured, seeing that omegas provide the most accurate estimate of reliability; values above 0.70 indicate good reliability (Revelle \& Zinbarg, 2009; Stone et al., 2013). Cronbach's alpha coefficients were also used to determine the reliability of the constructs measured in this study. A cut-off point of 0.70 , indicating high reliability, was applied (De Vos et al., 2011).

The following fit indices were considered to investigate the research model: the comparative fit index (CFI), Tucker-Lewis index (TLI) and root mean square error of approximation (RMSEA). For the CFI and TLI, acceptable fit is considered to be a value of 0.90 and above and for the RMSEA a value of 0.08 and below is to be considered an acceptable model fit (Byrne, 2010).

To investigate the mediation effects of work-to-family enrichment and family-to-work enrichment, the model indirect function of Mplus was specified. According to Rucker, Preacher, Tormala and Petty (2011, p. 359), attention in mediation analysis 'should be shifted towards the magnitude and significance of indirect effects'. Indirect 
effect refers to the reduction of the effect the initial variable has on the outcome variable; if the bias corrected 95\% confidence interval estimates do not go through zero, a significant mediation effect will be reported (Byrne, 2010; Rucker et al., 2011; Shrout \& Bolger, 2002). Therefore, the bootstrapping resampling option was enabled in Mplus and set to draw 5000 samples (Hayes, 2009). Kappa-squared $\left(\kappa^{2}\right)$ effect size values were also calculated to help establish a basis from which to communicate the magnitude of the mediating effects (Preacher \& Kelley, 2011). These values can be interpreted in the same light as squared correlation coefficients $\left(\mathrm{R}^{2}\right)$ and can thus be classified as a small (0.01), medium (0.09) or large (0.25) effect.

\section{Results}

\section{Fit statistics}

The research model was specified and the fit statistics for the measurement model were acceptable $(\mathrm{CFI}=0.96$; $\mathrm{TLI}=$ 0.96; RMSEA $=0.03$ ). Regression paths were then added to constitute the structural model and the following fit statistics were revealed: CFI 0.94, TLI 0.94 and RMSEA 0.04; these values were in an acceptable range (Van de Schoot, Lugtig \& Hox, 2012) and interpretation of results therefore continued.

\section{Correlations between the latent variables}

From the results in Table 2 it is evident that a positive relationship exists between all the variables. As can be seen, there are very high correlations between the individual latent indicators and the second-order latent variables, which supports the second-order latent factor approach taken as described in the statistical analysis section. Some of the following important relationships were evident: work resources were practically (large effects) and significantly correlated with work-family enrichment $(r=0.61)$ and work engagement $(r=0.64)$. Work-family enrichment was also positively correlated with work engagement $(r=0.50)$. These results therefore support Hypothesis $1 \mathrm{a}$, as a positive association is evident between the work resources and workto-family enrichment. Furthermore, Hypothesis $1 \mathrm{c}$ is also supported by the results, as a positive association is evident between work engagement and work-to-family enrichment.

Furthermore, home resources were practically correlated (medium effects) with family-work enrichment $(r=0.44)$, and also with family engagement $(r=0.43)$. Therefore, the results supported Hypothesis $1 b$, as a positive association is evident between the home resources and the family-work enrichment. Hypothesis 1d is also supported by the results, as it is evident that a positive association exists between family engagement and family-to-work enrichment $(r=$ 0.47). However, this relationship is also a medium effect.

Other noteworthy correlations were between work resources and home resources, which bordered on medium practical significance $(r=0.29)$, work engagement and family engagement ( $r=0.40$; medium effect) and between workfamily enrichment and family-work enrichment, which had a large practically significant association $(r=0.52)$.

\section{Regressions and mediation}

The results indicated a positive relationship between work resources and work-family enrichment $(\beta=0.89 ; p<0.001)$, as well as a positive relationship between work-family enrichment and work engagement $(\beta=0.54 ; p<0.001)$. Thus, Hypothesis 1a and Hypothesis 1c are fully supported, given the relationships between work-family enrichment and work resources, as well as between work-family enrichment and work engagement. Furthermore, bootstrapping revealed that work-to-family enrichment mediated the relation between

TABLE 2: Correlation matrix for the latent variables.

\begin{tabular}{|c|c|c|c|c|c|c|c|c|c|c|c|c|c|c|c|c|c|c|c|}
\hline Latent variables & 1 & 2 & 3 & 4 & 5 & 6 & 7 & 8 & 9 & 10 & 11 & 12 & 13 & 14 & 15 & 16 & 17 & 18 & 19 \\
\hline 1. Work-family perspectives & 1.00 & - & - & - & - & - & - & - & - & - & - & - & - & - & - & - & - & - & - \\
\hline 2. Family-work perspectives & $0.85^{b}$ & 1.00 & - & - & - & - & - & - & - & - & - & - & - & - & - & - & - & - & - \\
\hline 3. Work-family affect & $0.85^{b}$ & $0.83^{b}$ & 1.00 & - & - & - & - & - & - & - & - & - & - & - & - & - & - & - & - \\
\hline 4. Family-work affect & $0.41^{\mathrm{a}}$ & $0.43^{\mathrm{a}}$ & $0.47^{\mathrm{a}}$ & 1.00 & - & - & - & - & - & - & - & - & - & - & - & - & - & - & - \\
\hline 5. Family-work social capital & $0.40^{\mathrm{a}}$ & $0.42^{\mathrm{a}}$ & $0.46^{\mathrm{a}}$ & $0.95^{b}$ & 1.00 & - & - & - & - & - & - & - & - & - & - & - & - & - & - \\
\hline 6. Work-family social capital & $0.82^{b}$ & $0.79^{b}$ & $0.80^{\mathrm{b}}$ & $0.45^{\mathrm{a}}$ & $0.44^{\mathrm{a}}$ & 1.00 & - & - & - & - & - & - & - & - & - & - & - & - & - \\
\hline 7. Family-work time management & $0.38^{\mathrm{a}}$ & $0.40^{\mathrm{a}}$ & $0.44^{\mathrm{a}}$ & $0.92^{\mathrm{b}}$ & $0.88^{\mathrm{b}}$ & $0.42^{\mathrm{a}}$ & 1.00 & - & - & - & - & - & - & - & - & - & - & - & - \\
\hline 8. Work-family time management & $0.77^{b}$ & $0.74^{b}$ & $0.75^{b}$ & $0.43^{\mathrm{a}}$ & $0.41^{a}$ & $0.72^{b}$ & $0.40^{\mathrm{a}}$ & 1.00 & - & - & - & - & - & - & - & - & - & - & - \\
\hline 9. Family engagement & 0.03 & 0.05 & 0.07 & $0.47^{\mathrm{a}}$ & $0.45^{a}$ & 0.06 & $0.43^{\mathrm{a}}$ & 0.06 & 1.00 & & - & - & - & - & - & - & - & - & - \\
\hline 10. Work engagement & $0.45^{a}$ & $0.44^{a}$ & $0.44^{\mathrm{a}}$ & 0.25 & 0.24 & $0.43^{\mathrm{a}}$ & 0.23 & $0.40^{\mathrm{a}}$ & $0.40^{\mathrm{a}}$ & 1.00 & - & - & - & - & - & - & - & - & - \\
\hline 11. Work autonomy & $0.47^{\mathrm{a}}$ & $0.45^{\mathrm{a}}$ & $0.46^{\mathrm{a}}$ & 0.23 & 0.22 & $0.44^{\mathrm{a}}$ & 0.21 & $0.41^{\mathrm{a}}$ & 0.17 & $0.52^{b}$ & 1.00 & - & - & - & - & - & - & - & - \\
\hline 12. Home autonomy & 0.16 & 0.16 & 0.18 & $0.33^{\mathrm{a}}$ & $0.32^{\mathrm{a}}$ & 0.17 & $0.31^{\mathrm{a}}$ & 0.16 & $0.32^{\mathrm{a}}$ & 0.18 & 0.18 & 1.00 & - & - & - & - & - & - & - \\
\hline 13. Home social support & 0.19 & 0.20 & 0.22 & $0.42^{\mathrm{a}}$ & $0.40 a$ & 0.21 & $0.39^{a}$ & 0.20 & $0.40^{\mathrm{a}}$ & 0.23 & 0.22 & $0.72^{\mathrm{b}}$ & 1.00 & - & - & - & - & - & - \\
\hline 14. Work social support & $0.34^{\mathrm{a}}$ & $0.33^{\mathrm{a}}$ & $0.33^{\mathrm{a}}$ & 0.17 & 0.16 & $0.32^{\mathrm{a}}$ & 0.16 & $0.30^{\mathrm{a}}$ & 0.12 & $0.38^{\mathrm{a}}$ & $0.49^{\mathrm{a}}$ & 0.13 & 0.16 & 1.00 & - & - & - & - & - \\
\hline 16. Home development possibilities & 0.17 & 0.18 & 0.19 & $0.36^{\mathrm{a}}$ & $0.35^{a}$ & 0.18 & $0.34^{\mathrm{a}}$ & 0.17 & $0.35^{\mathrm{a}}$ & 0.20 & 0.19 & $0.62^{\mathrm{b}}$ & $0.77^{\mathrm{b}}$ & 0.14 & 0.21 & 1.00 & - & - & - \\
\hline 17. Work resources & $0.58^{b}$ & $0.55^{b}$ & $0.56^{b}$ & 0.28 & 0.27 & $0.54^{b}$ & 0.26 & $0.50^{b}$ & 0.21 & $0.64^{b}$ & $0.82^{b}$ & 0.22 & 0.27 & $0.60^{\mathrm{b}}$ & $0.87^{b}$ & 0.24 & 1.00 & - & - \\
\hline 18. Home resources & 0.21 & 0.21 & 0.23 & $0.44^{\mathrm{a}}$ & $0.43^{a}$ & 0.22 & $0.41^{a}$ & 0.21 & $0.43^{\mathrm{a}}$ & 0.24 & 0.24 & $0.76^{\mathrm{b}}$ & $0.94^{b}$ & 0.17 & 0.25 & $0.82^{\mathrm{b}}$ & 0.29 & 1.00 & - \\
\hline 19. Work-family enrichment & $0.94^{b}$ & $0.91^{\mathrm{b}}$ & $0.91^{b}$ & $0.52^{b}$ & $0.50^{\mathrm{b}}$ & $0.88^{b}$ & $0.48^{a}$ & $0.82^{b}$ & 0.07 & $0.49^{\mathrm{a}}$ & $0.50^{\mathrm{b}}$ & 0.19 & 0.24 & $0.37^{\mathrm{a}}$ & $0.53^{b}$ & 0.21 & $0.61^{\mathrm{b}}$ & 0.25 & 1.00 \\
\hline 20. Family-work enrichment & $0.42^{\mathrm{a}}$ & $0.44^{a}$ & $0.48^{\mathrm{a}}$ & $0.93^{b}$ & $0.96^{\mathrm{b}}$ & $0.46^{\mathrm{a}}$ & $0.92^{\mathrm{b}}$ & $0.43^{\mathrm{a}}$ & $0.47^{\mathrm{a}}$ & 0.25 & 0.23 & $0.34^{\mathrm{a}}$ & $0.42^{\mathrm{a}}$ & 0.17 & 0.24 & $0.36^{\mathrm{a}}$ & 0.28 & $0.44^{\mathrm{a}}$ & $0.52^{b}$ \\
\hline
\end{tabular}

a, Correlation $\geq 0.30$ is practically significant (medium effect)

, Correlation $\geq 0.50$ is practically significant (large effect)

All alpha and omega values were $\geq 0.70$ 
work resources and work engagement with a significant indirect effect that did not go through zero $(0.12 ; 95 \% \mathrm{CI}$ : $0.05,0.19)$. The $\kappa^{2}$ effect size value for the mediating effect of work-to-family enrichment between work resources and work engagement was calculated to be a medium effect $\left(\kappa^{2}=0.13\right)$.

Therefore, Hypothesis 2a is accepted fully, seeing that workfamily enrichment does mediate the relationship between work resources, leading to work engagement as an outcome amongst female workers.

The results further showed a positive relationship between home resources and family-work enrichment $(\beta=0.83$; $p<0.001)$, as well as between family-work enrichment and family engagement $(\beta=0.44 ; p<0.001)$. Results from bootstrapping revealed that family-to-work enrichment mediated the relationship between home resources and family engagement with a significant indirect effect that did not go through zero $(0.17 ; 95 \%$ CI: $0.10,0.23)$. The $\kappa^{2}$ effect size value for the mediating effect of family-to-work enrichment between home resources and family engagement was calculated to be a medium effect $\left(\kappa^{2}=0.16\right)$.

Therefore, Hypothesis $2 \mathrm{~b}$ is accepted fully, seeing that family-work enrichment does mediate the relationship between home resources, leading to family engagement as an outcome amongst female workers.

\section{Discussion}

\section{Outline of the results}

In South Africa, research on work-family enrichment with regard to female workers and the relationships between the antecedents and outcomes of work-family enrichment is limited (Britz, 2010; Jaga \& Bagraim, 2011; Jaga et al., 2013). The same can be said of assessing the mediating effect of work-family enrichment and family-work enrichment. Therefore, the present study adds to the existing literature investigating the positive side of the work-family interface (Britz, 2010; Jaga \& Bagraim, 2011; Jaga et al., 2013).

The objective of this study was to investigate the relationships between the various dimensions of work-family enrichment in both directions. These consisted of the following: work resources (i.e. work support, work-related developmental possibilities and work autonomy), home resources (i.e. home support, home-related developmental possibilities and home autonomy), work engagement, family engagement and work-family enrichment. Furthermore, a work-family enrichment model was also tested on a sample of female workers. This was done by using work-to-family enrichment dimensions as mediators between work resources and work engagement and family-to-work enrichment dimensions as mediators between home resources and family engagement.

\section{The relationship between work resources and work-to-family enrichment}

Hypothesis 1a was supported. The results indicated a positive relationship between work resources and work-to- family enrichment amongst female workers. The results of the association between work-family enrichment and work resources are also consistent with other research on this topic (Baral \& Bhargava, 2011; Beutell \& Wittig-Berman, 2008; Geurts et al., 2005; Hill, 2005; Innstrand et al., 2010; Karatepe \& Beketshi, 2008; Nicklin \& McNall, 2013; Voydanoff, 2004; Wadsworth \& Owens, 2007). From a COR theory perspective, this may imply that female workers who are involved in their work life may gain resources (such as work support, workrelated developmental possibilities and work autonomy), which they then can transfer to their family domain: a gain spiral (Hobfoll, 2001). These resources will help them to be a better family member and thus enhance the quality of their family life. It may further suggest that when support is available at work, female workers are likely to feel more positive and build on these supportive relationships. This may also give them the energy and skills that enable them to be in control of their work activities. Such skills and positive emotions may then be carried over to their family role, thus enhancing this role. Also, when support is available at work, female workers may be able to integrate their work and family responsibilities better, seeing that this support can help to bridge the boundaries between work life and family life, and in that sense this experience of support can serve to reinforce their experience of work-family enrichment (Baral \& Bhargava, 2011; Winfield \& Rushing, 2005).

When female workers have more sense of control over their work and when their job is being enriched with opportunities to learn and to obtain new skills, these may be transferred to their family; such resources may thus affect how they feel about their management of family responsibilities and thereby enhance their competency as a family member (Baral \& Bhargava, 2011). When an organisation provides a female worker with opportunities to progress in the organisation, she may then acquire new skills, perspectives and mental sharpness that may cause her to feel more positive about herself and her work. Such a female worker will then be able to carry these resources into her family domain, thus enriching her family life. This is consistent with research that found that when self-reported learning opportunities are present at work, it is associated with an increase of workfamily enrichment (Voydanoff, 2004). Furthermore, previous research on certain dimensions of work-family enrichment and their relationships with certain antecedents has delivered the following findings: work-family development, work-family affect and work-family capital were shown to be related positively to developmental experiences at work, work autonomy and relation with supervisor (form of support) (Carlson et al., 2006).

\section{The relationship between home resources and family-to-work enrichment}

The results also confirm Hypothesis $1 \mathrm{~b}$ : evidence exists for a positive association between home resources (i.e. home support, home-related developmental possibilities and home autonomy) and the various dimensions of family-to-work enrichment amongst female workers. Previous studies have also found a sound relationship between home resources, 
such as home support and family-to-work enrichment (Aryee et al., 2005; Baral \& Bhargava, 2011; Grzywacz \& Marks, 2000; Karatepe \& Bekteshi, 2008; Wayne, Randel \& Stevens, 2006). More specifically, and in line with COR theory, this may imply that when female workers experience a true family life and are involved in their family life, they may gain resources (such as home support, home-related developmental possibilities and home autonomy) from their family life which they then can transfer and apply to their work domain. This transfer of resources will help them to be a better worker and enhance the quality of their work. More specifically, the support female workers receive from home may encourage them to feel more positive about their work and enable them to gain skills and perspectives that they can apply to work. This may also allow them to have better control over pace and time and enable them to work longer hours and invest more energy into their work (Aryee et al., 2005; Baral \& Bhargava, 2011; Greenhaus \& Parasuraman, 1999). This, in turn, may lead to an increase in performance and satisfaction at work (Baral \& Bhargava, 2011).

The availability of developmental possibilities and autonomy at home may also increase the probability of female workers having more resources to apply in their work life, thereby enhancing their work life. This may be because if female workers feel that they have more sense of control over activities at home and have opportunities at home to improve their family life, they may feel more equipped to acquire self-concept, skills and perspectives, and better time-management, which in turn can enhance the quality of their work life.

\section{The relationship between work-to-family enrichment and work engagement}

The results also confirm Hypothesis 1c, indicating that a positive relationship exists between work engagement and the dimensions of work-to-family enrichment (workfamily perspectives, work-family affect, work-family socialcapital and work-family time-management). This is also supported by previous research that found a positive relation between work-to-family enrichment and work engagement (Hakanen et al., 2011), and also that positive involvement in both work life and family life can lead to engagement at work (Montgomery, Peeters, Schaufeli \& Den Ouden, 2003; Mostert, Cronje \& Pienaar, 2006; Van Aarde \& Mostert, 2008). This may indicate that when female workers experience increasing work-to-family enrichment, they are more likely to experience engagement in their work. More specifically, and as presented in COR theory, it may mean that when a female worker gains resources (i.e. work support, workrelated developmental possibilities and work autonomy) from her work life and transfers these resources to her family life, she is more likely to feel engaged in her work. The reason may be that the resources female workers gain from their work enhance and improve the quality of their family life. Female workers might therefore feel more engaged in their work, seeing that they experience their work as a source enabling them to be better family members.
From this a directive can be inferred for organisations: they should focus on providing resources for their female workers, because, as was indicated above, female workers are likely to apply the resources they gain at work to their family life and thus enhance the quality of that life. Therefore, organisations are likely to benefit, since female workers will be more engaged at work. Studies have shown that when female workers experience enrichment at home, it may improve their vigour, absorption and dedication at work (Hakanen et al., 2011). For example, when female workers are more involved in their work, they may experience more energy in and enthusiasm towards their work.

\section{The relationship between family-to-work enrichment and family engagement}

Hypothesis 1d posited a positive relationship between family engagement and family-to-work enrichment amongst female workers. In line with COR theory, this may suggest that when female workers gain resources (i.e. home support, homerelated developmental possibilities and home autonomy) from home and transfer these resources to their work, thus experiencing family-to-work enrichment, they are then more likely to experience family engagement. More specifically, they may view their family life as a source to make them a better family member, which enables them to feel more engaged towards their work. This finding is also in line with a study (Graves et al., 2007) that found that when family experiences generate resources, that may then in turn lead to more engagement in family life.

\section{The mediating role of work-family enrichment and family-work enrichment}

The results showed an adequate fit for the model tested where work-to-family enrichment and family-to-work enrichment acted as mediators. Hypothesis $2 \mathrm{a}$ and Hypothesis $2 \mathrm{~b}$ were also confirmed by the results. Hypothesis 2a stated that work-family enrichment mediates (with a medium effect) the relationship between work resources, leading to work engagement as an outcome amongst female workers. This may suggest that when female workers have more work resources available (support, autonomy and developmental possibilities) they could experience higher work-to-family enrichment, which in turn may lead to increased engagement at work. Work resources are therefore also needed for female workers to experience work-family enrichment, seeing that work resources enhance work-family enrichment. If female workers then do experience work-family enrichment, the chances are good that they will also experience work engagement. More specifically, work-family enrichment is needed in the relationship between work resources and work engagement. This is because this experience of workfamily enrichment increases the chance of experiencing work engagement (Hakanen et al., 2011).

Hypothesis $2 \mathrm{~b}$ stated that family-work enrichment mediates (with a medium effect) the relationship between home resources, leading to family engagement as an outcome amongst female workers. This may indicate, similar to 
Hypothesis 2a, that when home resources are available, female workers are more likely to experience higher familyto-work enrichment, which might then lead to an increase in family engagement. Family-to-work enrichment is therefore needed in the relationship between home resources and family engagement to enhance the experience of how home resources, through family-to-work enrichment, can lead to increased engagement in family life. Other studies have also found evidence to confirm this mediating effect of the concept work-family enrichment (Baral \& Bhargava, 2010; McNall et al. 2010; Nicklin \& McNall, 2013).

Both of the mediation results are in line with COR theory and the positive gain spiral that has been suggested (Hobfoll, 2001). Therefore, resource gains result in positive gains which can then lead to more gains in terms of wellbeing and motivation (engagement) (cf. Salanova, Schaufeli, Xanthopoulou \& Bakker, 2010). Work-to-family enrichment and family-to-work enrichment therefore seem to play an important indirect role in the obtainment of both work and family engagement through the applicable resources.

\section{Practical implications}

The results provide more insight and understanding to organisations and female workers on the potential benefits of being involved in both the domains of work life and family life. Current evidence supports the possibility that if a female worker experiences W-FE, she is more likely to be a productive employee and may experience less occupational stress, more job satisfaction, commitment and engagement in her work (Franks et al., 2006; Mostert et al., 2006; Montgomery et al., 2003; Van Aarde \& Mostert, 2008). Organisations should therefore consider the enhancement of the antecedents (work resources) of work-family enrichment as this can potentially lead to desired outcomes such as improved work engagement. More specifically, it could benefit organisations if management focuses on providing these resources, as female workers could possibly transfer these resources to their family domain. This may possibly enhance the quality of their family life, which in turn could lead to engagement in their work life.

The evidence presented here should lead organisations to question their role in valuing their employees' family life. This is because female workers who enjoy a quality family life could be more likely to develop into a better worker, which may therefore also enhance their engagement at work (Hakanen et al., 2011). Female workers can also focus on generating the antecedents (home resources) that can lead to family-work enrichment and in turn result in improved family engagement. Therefore, the more resources generated at home, such as support, autonomy and developmental possibilities, the more they are likely to experience family-towork enrichment, which then can lead to them experiencing family engagement.

\section{Limitations and recommendations}

The present study is not without its limitations, which should be noted. The first limitation is that a cross-sectional research design was used, which means that the data was gathered at one point in time (De Vos et al., 2011). As a result, no casual inferences could be drawn amongst the variables and the researcher was therefore not able to establish a causal relationship (Oosthuizen, 2011). This method also does not allow for the changing values of the variables that were used in this study to be measured over time (Olwage, 2012). It is therefore essential and recommended that longitudinal research designs are used in future research. The reason is that longitudinal designs are used to study change in the same sample over a period of time (Ployhart \& Vandenberg, 2010). Therefore, using longitudinal studies will increase the validation of the hypothesised causalities of the relationships. Such studies will show whether the tested relationships are also true and accurate over a period of time (Montgomery et al., 2003; Oosthuizen, 2011). In addition, the use of this method will help researchers to acquire more integrated data and thus help to decrease research bias (Olwage, 2012).

A second limitation is that the study made use of only selfreported questionnaires. This type of questionnaire is a practical way of obtaining meaningful information and can be seen as a cost-effective method for data collection (Olwage, 2012). However, this can be seen as a limitation as this could lead to a rise in the common method variance problem; also, the use of only a single method of data collection may increase the likelihood that associations could be false and insignificant (Olwage, 2012; Oosthuizen, 2011). Such a method can also lead to unfairness because respondents' personal perceptions are being measured and it may be difficult to distinguish between the constructs that are measured (Olwage, 2012).

Thirdly, the study was done on a homogeneous sample consisting of only women. Therefore, almost no attention has been given to whether the experience of $\mathrm{W}$-FE is gender specific (Baral \& Bhargava, 2011). However, since women still tend to carry most of the home responsibilities (Franks et al., 2006) and are thus more likely to experience W-FE, it seemed sensible to make use of only a sample of female workers. It should also be noted that, in the South African context, only limited research has been done on W-FE. Thus, a study focusing on a good sample of female workers fills an important gap. However, future researchers should make it their objective to investigate this W-FE phenomenon amongst a sample of male workers in South Africa as well. In the past it has indeed been found that men and women experience different relationships between their work and family domains (Greenhaus \& Parasuraman, 1999). Men may also experience work-family enrichment differently, as their household situation differs from than that of women. For example, men may give more priority to being the breadwinner, and women may give more priority to being the homemaker and mother (Ezzedeen \& Ritchey, 2009; Gutek, Searle \& Klepa, 1991; Rothbard, 2001).

Lastly, this study only focused on certain antecedents and outcomes of work-family enrichment; therefore, it 
is recommended that future research investigates other antecedents and outcomes for work-family enrichment and their possible relationships with work-family enrichment can also be assessed.

There are also recommendations that can be proposed for organisations. Firstly, it is crucial for organisations to understand the significance of work-family enrichment and how this concept influences their female employees, and in turn the organisation. A better understanding of work-family enrichment will also help the organisation to encourage female workers to use the resources they gain from work to benefit them. For example, organisations can ensure that they have sufficient resources available at work to which female workers can have access. These employees will then be able to transfer the resources to their family life and enhance the quality of that life. As indicated from the study, work resources include support (supervisor and social), workrelated developmental possibilities and autonomy.

Secondly, managers can ensure that there is sufficient support available in their organisation, for example adequate supervisory relationships. This can be done by the supervisor being available for the employees and by maximising the relationship, seeing that an average relationship is not good enough (Mostert, 2012). Organisations may also wish to provide training for supervisors, in order to educate them on the importance of supervisor support for their subordinates; supervisors can also be trained to show supportive behaviour towards their employees (Franks et al., 2006). In addition, organisations can ensure that employees have access to other employees in order to promote social support at work.

Thirdly, work-related developmental possibilities have been shown to be a very strong driver for finding psychological meaning in work (Mostert, 2012) and therefore also an important resource at work. Work-related developmental possibilities can include variety and opportunities to learn (Mostert, 2012). Organisations can ensure that work has variety by including an assortment of tasks in job assignments. Opportunities to learn must also be made available for employees, seeing that learning opportunities require new skills, as well as the need to be innovative and creative (Mostert, 2012). This in turn can ensure that resources are transferred to the family life.

Fourthly, organisations need to ensure that their employees enjoy autonomy at work. To accomplish this, organisations can trust in their employees' ability to be independent with their work activities and work content. This is because autonomy allows for flexibility in the planning of work activities (Mostert, 2012).

Lastly, organisations can encourage their workers to have a positive family life and to utilise the resources gained from their family life to enhance their work life. Organisations can accomplish this by implementing intervention plans, such as a short workshop on how to be involved positively with one's family life. Other possible interventions are to re-design jobs in order to provide employees with more autonomy, to provide benefits and policies such as flexitime and to develop a family-friendly organisational culture at the workplace (Baral \& Bhargava, 2010). Research has also found that by having such interventions, positive benefits will be reaped on certain job outcomes such as employees' level of commitment, engagement and job satisfaction (Allen, 2001; Gordon et al., 2007; Hackman \& Oldham, 1976; Kossek \& Ozeki, 1998; Kopelman, Prottas, Thompson \& Jahn, 2006; Lambert, 2000; Thomas \& Ganster, 1995; Thompson, Beauvais \& Lyness, 1999).

\section{Conclusions}

In conclusion, the results indicate a definite relationship between work resources (i.e. work support, work-related developmental possibilities and work autonomy), workfamily enrichment and work engagement. They also indicate a relationship between home resources (i.e. home support, home-related developmental possibilities and home autonomy), family-work enrichment and family engagement. The results furthermore confirm the mediating effect of work-to-family enrichment in the relationship between work resources and work engagement. They also establish familyto-work enrichment as being a mediator between home resources and family engagement. This research study thus contributes to the positive side of the work-family interface by investigating work-family enrichment and its antecedents and outcomes amongst female workers within the South African context.

\section{Acknowledgements}

The authors would also like to acknowledge the anonymous reviewers for their guidance in revising the manuscript.

\section{Competing interests}

The authors declare that they have no financial or personal relationship(s) that may have inappropriately influenced them in writing this article.

\section{Authors' contributions}

E.M. (North-West University) collected the data and took the lead in the write-up of the manuscript. M.D.K. (NorthWest University) acted as supervisor for E.M., assisted and gave valuable insight into the write-up of the manuscript. J.A.N. (North-West University) acted as co-supervisor and gave insight into the write-up of the manuscript. L.D.B. (North-West University) acted as corresponding author, performed the statistical analysis and supervised the write-up of the results.

\section{References}

Allen, T.D. (2001). Family-supportive work environments: The role of organizationa perceptions. Journal of Vocational Behaviour, 58(3), 414-435. http://dx.doi. org/10.1006/jvbe.2000.1774

Aryee, S., Srinivas, E.S., \& Tan, H.H. (2005). Rhythms of life: Antecedents and outcomes of work-family balance in employed parents. The Journal of Applied Psychology, 90, 132-146. http://dx.doi.org/10.1037/0021-9010.90.1.132 
Bakker, A.B., Demerouti, E., \& Verbeke, W. (2004). Using the job demands-resources model to predict burnout and performance. Human Resource Management, 43, 83-104. http://dx.doi.org/10.1002/hrm.20004

Balmforth, K., \& Gardner, D. (2006). Conflict and facilitation between work and family: Realising the outcomes for organizations. New Zealand Journal of Psychology, 35, 69-76

Baral, R., \& Bhargava, S. (2010). Work-family enrichment as a mediator between organizational interventions for work-life balance and jo outcomes. Journal of Managerial Psychology, 25(3), 274-300. http://dx.doi. org/10.1108/02683941011023749

Baral, R., \& Bhargava, S. (2011). Examining the moderating influence of gender on the relationships between work-family antecedents and work-family enrichment. Gender in Management: An International Journal, 26(2), 122-147. http://dx.doi.org/10.1108/17542411111116545

Barnett, R.C. (1998). Toward a review and reconceptualization of the work/family literature. Genetic, Social, and General Psychology Monographs, 124, 125-182.

Barnett, G.C., \& Baruch, G.K. (1985). Women's involvement in multiple roles, role strain, and psychological distress. Journal of Personality and Social Psychology, 49 135-154. http://dx.doi.org/10.1037/0022-3514.49.1.135

Barnett, G.C., \& Hyde, J.S. (2001). Women, men, work and family: An expansionis theory. American Psychologist, 56(10), 781-796. http://dx.doi.org/10.1037/0003066X.56.10.781

Beutell, N.J., \& Wittig-Berman, U. (2008). Work-family conflict and work-family synergy for generation $\mathrm{X}$, baby boomers, and matures: Generational differences, predictors, and satisfaction outcomes. Journal of Managerial Psychology, 23(5), 507-523. http://dx.doi.org/10.1108/02683940810884513

Bezuidenhout, A., \& Cilliers, F.V.N. (2010). Burnout, work engagement and sense of coherence in female academics in higher-education institutions in South Africa. South African Journal of Industrial Psychology, 36(1), 1-10.

Boixados, M., Hernandez, E., Guillamon, N., \& Pousada, M. (2010). Working women's lifestyles and quality of life in the Information society. Health Care for Women lifestyles and quality of life in the Information society. Health Care for Wom
International, 31(6), 552-567. http://dx.doi.org/10.1080/07399331003721365

Britz, Y. (2010). Exploring the relationship between work and non-work roles of parenting males at a higher education institution, Unpublished master's dissertation, School of Human Resource Sciences, North-West University, Potchefstroom, South Africa.

Byrne, B.M. (2010). Structural equation modeling with AMOS: Basic concepts, applications and programming. (2nd edn.). Mahwah, NJ: Lawrence Erlbaum Associates Inc. Publishers.

Carlson, D.S., Kacmar, K.M., Wayne, J.H., \& Grzywacz, J.G. (2006). Measuring the positive side of the work-family interface: Development and validation of a workfamily enrichment scale. Journal of Vocational Behavior, 68, 131-164. http:// dx.doi.org/10.1016/j.jvb.2005.02.002

Cheng, T., Mauno, S., \& Lee, C. (2013). Do job control, support, and optimism help job insecure employees? A three-wave study of buffering effects on job satisfaction, vigor and work-family enrichment. Social Indicators Research, 118, 1-23.

De Beer, L.T., Pienaar, J., \& Rothmann, S. Jnr. (2013). Investigating the reversed causality of engagement and burnout in job demands-resources theory. South
African Journal of Industrial Psychology, 39(1), 1-9. http://dx.doi.org/10.4102/ African Journal
sajip.v39i1.1055

De Klerk, M., Nel, J.A., Hill, C., \& Koekemoer, E. (2013). The development of the MACE Work-Family Enrichment Instrument. South African Journal of Industrial Psychology, 39(2), 1147-1162.

De Vos, A.S., Strydom, H., Fouché, C.B., \& Delport, C.S.L. (2011). Research at grass roots: For the social sciences and human service professions. (4th edn.) Pretoria South Africa: Van Schaik.

Demerouti, E. (2012). The spillover and crossover of resources among partners: The role of work-self and family-self facilitation. Journal of Occupational Health Psychology, 17, 184-195. http://dx.doi.org/10.1037/a0026877

Demerouti, E., \& Bakker, A.B. (2011). The Job Demands-Resources model: Challenges for future research. South African Journal of Industrial Psychology, 37(2), 1-9.

Demerouti, E., Bakker, A.B., \& Voydanoff, P. (2010). Does home life interfere with or facilitate job performance? European Journal of Work and Organisational
Psychology, 19(2), 128-149. http://dx.doi.org/10.1080/13594320902930939

Demerouti, E., Geurts, S.A.E., \& Kompier, M. A. J. (2004). Positive and negative workhome interaction: Prevalence and correlates. Equal Opportunities International, 23, 6-35. http://dx.doi.org/10.1108/02610150410787837

Edwards, J.R., \& Rothbard, N.P. (2000). Mechanisms linking work and family: Clarifying the relationship between work and family constructs. Academy of Management Review, 25, 178-199. http://dx.doi.org/10.2307/259269

Ezzedeen, S.R., \& Ritchey, K.G. (2009). Career advancement and family balance strategies of executive women. Gender in Management: An International Journal strategies of executive women. Gender in Management: An Internat
24(6), 388-411. http://dx.doi.org/10.1108/17542410910980388

Fernandez, R. (2013). Cultural change as learning: The Evolution of female labor force participation over a century. American Economic Review, 103(1), 472-500. http:// dx.doi.org/10.1257/aer.103.1.472

Franks, K., Schurink, W., \& Fourie, L. (2006). Exploring the social construction of life roles of career-oriented women. South African Journal of Industrial Psychology, 32(1), 17-24

Friedman, S.D., \& Greenhaus, J.H. (2000). Work and family - allies or enemies? What happens when business professionals confront life choices. New York, NY: Oxford University Press. http://dx.doi.org/10.1093/acprof:0 so/9780195112757.001.0001

Frone, M.R. (2003). Work-family balance. In J.C. Quick, \& L.E. Tetrick (Eds.), Handbook of Occupational Health Psychology (pp. 143-162). Washington, DC: American Psychological Association. http://dx.doi.org/10.1037/10474-007
Frone, M.R., \& Rice, R.W. (1987). Work-family conflict: The effect of job and family involvement. Journal of Occupational Behavior, 11, 79-96.

Frone, M.R., Russell, M., \& Cooper, M.L. (1992). Antecedents and outcomes of workfamily conflict: Testing a model of the work-family interface. Journal of Applied Psychology, 77, 65-78. http://dx.doi.org/10.1037/0021-9010.77.1.65

Gareis, K., Barnett, R.C., Ertel, K.A., \& Berkman, L.F. (2009). Work-family enrichment and conflict: Additive effects, buffering, or balance? Journal of Marriage and Family, 71, 696-707. http://dx.doi.org/10.1111/j.1741-3737.2009.00627.x

Geurts, S.A.E., Taris, T.W., Kompier, M.A.J., Dikkers, J.S.E., Van Hooff, M.L.M., \& Kinnunen, U.M. (2005). Work-home interaction from a work psychological perspective: Development and validation of a new questionnaire, the SWING Work \& Stress, 19, 319-339. http://dx.doi.org/10.1080/02678370500410208

Gillespie, N.A., Walsh, M., Winefield, A.H., Dua, J., \& Stough, C. (2001). Occupational stress in universities: Staff perceptions of the causes, consequences and moderators of stress. Work \& Stress, 15, 53-72. http://dx.doi.org/10.1080/02678370117944

Gordon, J.R., Whelan-Berry, K., \& Hamilton, E.A. (2007). The relationship among workfamily conflict and enhancement, organizational work-family culture, and work family conflict and enhancement, organizational work-family culture, and work
outcomes for older working women. Journal of Occupational Health Psychology, outcomes for older working women. Journal of Occupational He
12(4), 350-364. http://dx.doi.org/10.1037/1076-8998.12.4.350

Graves, L.M., Ohlott, P.J., \& Ruderman, M.N. (2007). Commitment to family roles: Effects on managers' attitudes and performance. Journal of Applied Psychology, 92, 44-56. http://dx.doi.org/10.1037/0021-9010.92.1.44

Greenhaus, J.H., \& Parasuraman, S. (1999). Research on work, family, and gender: Current status and future directions. In G.N. Powell (Ed.), Handbook of gender and work (pp. 391-412). Newbury Park, CA: Sage.

Greenhaus, J.H., \& Powell, G. (2006). When work and family are allies: A theory of work-family enrichment. Academy of Management Review, 31(1), 72-92. http://dx.doi.org/10.5465/AMR.2006.19379625

Grzywacz, J.G., \& Marks, N.F. (2000). Reconceptualizing the work-family interface: An ecological perspective on the correlates of positive and negative spillover between work and family. Journal of Occupational Health Psychology, 5, 111-126. http://dx.doi.org/10.1037/1076-8998.5.1.111

Gutek, B.A., Searle, S., \& Klepa, L. (1991). Rational versus gender role explanations for work-family conflict. Journal of Applied Psychology, 76(4), 560-568. http://dx.doi. org/10.1037/0021-9010.76.4.560

Hackman, J.R., \& Oldham, G.R. (1976). Motivation through the design of work: Test of a theory. Organizational Behaviour and Human Performance, 16, 250-279. of a theory. Organizational Behaviour and Human
$\mathrm{http}: / / \mathrm{dx}$.doi.org/10.1016/0030-5073(76)90016-7

Hakanen, J.J., Bakker, A.B., \& Schaufeli, W.B. (2006). Burnout and work engagement among teachers. Journal of School Psychology, 34, 495-513. http://dx.doi. org/10.1016/j.jsp.2005.11.001

Hakanen, J.J., Peeters, M.C., \& Perhoniemi, R. (2011). Enrichment processes and gain spirals at work and at home: A 3-year cross-lagged panel study. Journal of Occupational and Organizational Psychology, 84, 8-30. http://dx.doi.org/10.1111/j.2044-8325.2010.02014.x

Halbesleben, J.R.B., \& Wheeler, A.R. (2008). The relative roles of engagement and embeddedness in predicting job performance and intention to leave. Work \& Stress, 22, 242-256. http://dx.doi.org/10.1080/02678370802383962

Halbesleben, J.R.B., Harvey, J., \& Bolino, M.C. (2009). Too engaged? A conservation of resources view of the relationship between work engagement and work interference with family. Journal of Applied Psychology, 49(6), 1452-1465. http://dx.doi.org/10.1037/a0017595

Hanson, G.C., Hammer, L.B., \& Colton, C.L. (2006). Development and validation of a multidimensional scale of perceived work-family positive spillover. Journal of Occupational Health Psychology, 11(3), 249-265. http://dx.doi.org/10.1037/10768998.11.3.249

Hayes, A.F. (2009). Beyond Baron and Kenny: Statistical mediation analysis in the new millennium. Communication Monographs, 76, 408-420. in the new millennium. Communication

Hill, E.J. (2005). Work-family facilitation and conflict, working fathers and mothers, work-family stressors and support. Journal of Family Issues, 26, 793-819. $\mathrm{http} / / / \mathrm{dx}$.doi.org/10.1177/0192513X05277542

Hobfoll, S.E. (1989). Conservation of resources: A new attempt at conceptualizing stress. American Psychologist, 44, 513-524. http://dx.doi.org/10.1037/0003066X.44.3.513

Hobfoll, S.E. (2001). The influence of culture, community, and the nested-self in the stress process: advancing conservation of resources theory. Applied Psychology: An International Review, 50, 337-421. http://dx.doi.org/10.1111/14640597.00062

Hobfoll, S.E. (2002). Social and psychological resources and adaptation. Review of General Psychology, 6, 307-324. http://dx.doi.org/10.1037/1089-2680.6.4.307

Hunter, E.M., Perry, S.J., Carlson, D.S., \& Smith, S.A. (2010). Linking team resources to work-family enrichment and satisfaction. Journal of Vocational Behavior, 77 to work-family enrichment and satisfaction. Journal of
304-312. http://dx.doi.org/10.1016/j.jvb.2010.05.009

Innstrand, S.T., Langballe, E.M., \& Falkum, E. (2010). Exploring occupational differences in work-family interaction: Who is at risk? International Journal of Stress Management, 27(1), 38-55. http://dx.doi.org/10.1037/a0018565

Jaga, A., \& Bagraim, J. (2011). The relationship between work-family enrichment and work-family satisfaction outcomes. South African Journal of Psychology, 41(1), 52-62.

Jaga, A., Bagraim, J., \& Williams, Z. (2013). Work-family enrichment and psychologica health. South African Journal of Industrial Psychology, 39(2), 1-10.

Kacmar, K.M., Crawford, W.S., Carlson, D.S., Ferguson, M., \& Whitten, D. (2014). A short and valid measure of work-family enrichment. Journal of Occupationa Health Psychology, 19, 32-45. http://dx.doi.org/10.1037/a0035123 
Karatepe, O.M., \& Bekteshi, L. (2008). Antecedents and outcomes of work-family facilitation and family-work facilitation among frontline hotel employees. facilitation and family-work facilitation among frontline hote employees.
International Journal of Hospitality Management, 27(4), 517-528. http://dx.doi. org/10.1016/j.ijhm.2007.09.004

Koekemoer, E., Mostert, K., \& Rothmann, S. Jr. (2010). Interference between work and nonwork roles: The development of a new South African instrument. SA Journal of Industrial Psychology/SA Tydskrif vir Bedryfsielkunde, 36(1), 1-4.

Kopelman, R.E., Prottas, D.J., Thompson, C.A., \& Jahn, E.W. (2006). A multi-level examination of work-life practices: Is more always better? Journal of Managerial Issues, 18, 232-253.

Kossek, E.E., \& Ozeki, C. (1998). Work-family conflict policies and the job-life satisfaction relationship: A review and directions for organizational behaviourhuman resources research. Journal of Applied Psychology, 83, 139-149. http:// dx.doi.org/10.1037/0021-9010.83.2.139

Lambert, S.J. (2000). Added benefits: The link between work-life benefits and organizational citizenship behaviour. Academy of Management Journal, 43, 801 815. http://dx.doi.org/10.2307/1556411

Lewis, S. (1997). An international perspective on work-family issues. In S. Parasuraman \& J.H. Greenhaus (Eds.), Integrating work and family: Challenges and choices for 0 changing world (pp. 91-103). Westport, CT: Quorom.

Marks, S.R. (1977). Multiple roles and role strain: Some notes on human energy, time and commitment. American Sociological Review, 42, 921-936. http://dx.doi. org/10.2307/2094577

McLellan, K., \& Uys, K. (2009). Balancing dual roles in self-employed women: An exploratory study. South African Journal of Industrial Psychology, 35(1), 1-10.

McNall, L.A., Masuda, A.D., \& Nicklin, J.M. (2010). Flexible work arrangements, job satisfaction, and turnover intentions: The mediating role of work-tofamily enrichment. The Journal of Psychology, 144, 61-81. http://dx.doi. org/10.1080/00223980903356073

Montgomery, A.J., Peeters, M.C.W., Schaufeli, W.B., \& Den Ouden, M. (2003). Workhome interference among newspaper managers: Its relationship with burnout and engagement. Anxiety, Stress, and Coping, 16(2), 195-211. http://dx.doi.org /10.1080/10615806.2003.10382973

Mostert, K. (2012, 17 February). Employee Wellness. Workshop presented for the course IOPS 616 (Employee Wellness), North-West University, Potchefstroom, South Africa.

Mostert, K., Cronje, S., \& Pienaar, J. (2006). Job resources, work engagement and the mediating role of positive work-home interaction of police officers in the North West Province. Acta Criminologica, 19(3), 64-87.

Muthén, L.K., \& Muthén, B.O. (2013). Mplus User's Guide. (7th edn.). Los Angeles, CA Muthén \& Muthén.

Nicklin, J.M., \& McNall, L.A. (2013). Work-family enrichment, support, and satisfaction: A test of mediation. European Journal of Work and Organizational Psychology, 22(1), 67-77. http://dx.doi.org/10.1080/1359432X.2011.616652

Odle-Dusseau, H.N., Britt, T.W., \& Greene-Shortridge, T.M. (2012). Organizational work family resources as predictors of job performance and attitudes: The process of work-family conflict and enrichment. Journal of Occupational Health Psychology, 17, 28-40. http://dx.doi.org/10.1037/a0026428

Olwage, D. (2012). Predictors of burnout and engagement of university students. Unpublished doctoral thesis, School of Human Resource Sciences, North-West University, Potchefstroom, South Africa.

Oosthuizen, J. (2011). Job characteristics, work-nonwork interference and the role of recovery strategies among employees in a tertiary institution. Unpublished doctoral thesis, School of Human Resource Sciences, North-West University, Potchefstroom, South Africa.

Parasuraman, S., Purohit, Y.S., Godshalk, V.M., \& Beutell, N.J. (1996). Work and family variables, entrepreneurial career success, and psychological well-being. Journal of Vocational Behavior, 48(3), 275-300. http://dx.doi.org/10.1006/jvbe.1996.0025

Ployhart, R.E., \& Vandenberg, R.J. (2010). Longitudinal research: The theory, design and analysis of change. Journal of Management, 36(1), 94-120. http://dx.doi org/10.1177/0149206309352110

Powell, G., \& Greenhaus, J. (2004). Is the opposite of positive negative? The relationship between work-family enrichment and conflict. New Orleans, LA Academy of Management Meetings.

Preacher, K.J., \& Kelley, K. (2011) Effect sizes measures for mediation models: Quantitative strategies for communicating indirect effects. Psychological Methods, 16, 93-115.

Rantanen, J., Kinnunen, U., Mauno, S., \& Tillemann, K. (2011). Introducing theoretica approaches to work-life balance and testing a new typology among professionals. In S. Kaiser, M. Ringlstetter, D. Eikhof, \& M. Cunha (Eds.), Creating balance?! International perspectives on the work-life integration of professionals (pp. 2746). Berlin/Heidelberg, Germany: Springer.

Revelle, W., \& Zinbarg, R.E. (2009). Coefficients alpha, beta, omega, and the GLB: Comments on Sijtsma. Psychometrika, 74, 145-154. http://dx.doi.org/10.1007/ s11336-008-9102-z

Rothbard, N.P. (2001). Enriching or depleting? The dynamics of engagement in work and family roles. Administrative Science Quarterly, 46, 655-684. http://dx.doi. org/10.2307/3094827

Rucker, D.D., Preacher, K.J., Tormala, Z.L., \& Petty, R.E. (2011). Mediation analysis in social psychology: Current practices and new recommendations. Social and Personality Psychology Compass, 5(6), 359-371. http://dx.doi.org/10.1111/ j.1751-9004.2011.00355.x

Ruderman, M.N., Ohlott, P.J., Panzer, K., \& King, S.N. (2002). Benefits of multiple roles for managerial females. Academy of Management Journal, 45(2), 369-386. http://dx.doi.org/10.2307/3069352
Saks, A.M. (2006). Antecedents and consequences of employee engagement Journal of Managerial Psychology, 27, 600-619. http://dx.doi. org/10.1108/02683940610690169

Salanova, M., Agut, S., \& Peiró, J.M. (2005). Linking organizational resources and work engagement to employee performance and customer loyalty: The mediation of service climate Journal of Applied Psychology, 90, 1217-1227. http://dx.doi. org/10.1037/0021-9010.90.6.1217

Salanova, M., Schaufeli, W.B., Xanthopoulou, D., \& Bakker, A.B. (2010). The gain spiral of resources and work engagement: Sustaining a positive worklife. In A.B. Bakker, \& M.P. Leiter (Eds.), Work engagement: A handbook of essential theory and research (pp. 118-131). New York, NY: Psychology Press.

Schaufeli, W.B., Salanova, M., González-Romá, V., \& Bakker, A.B. (2002) The measurement of engagement and burnout: A confirmative analytic approach. Journal of Happiness Studies, 3(1), 71-92. http://dx.doi. org/10.1023/A:1015630930326

Schutte, N., Toppinen, S., Kalimo, R., \& Schaufeli, W.B. (2000). The factorial validity of the Maslach Burnout Inventory-General Survey (MBI-GS) across occupationa groups and nations. Journal of Occupational and Organizational Psychology, 73, 53-66. http://dx.doi.org/10.1348/096317900166877

Shrout, P.E., \& Bolger, N. (2002) Mediation in experimental and non-experimental studies: New procedures and recommendations. Psychological Methods, 7,422 445. http://dx.doi.org/10.1037/1082-989X.7.4.422

Sieber, S.D. (1974). Toward a theory of role accumulation. American Sociological Review, 39, 567-578. http://dx.doi.org/10.2307/2094422

Siu, O., Lu, J., Brough, P., Lu, C., Bakker, A., Kalliath, T. et al. (2010). Role resources and work-family enrichment: The role of work engagement. Journal of Vocational Behavior, 77, 470-480.

Statistics South Africa. (2001). Census 2001. Retrieved July 10, 2013, from http:/www. statssa.gov.za

Statistics South Africa. (2011). Census 2011. Retrieved July 10, 2013, from http:/www. statssa.gov.za

Stone, L.L., Otten, R., Ringlever, L., Hiemstra, M., Engels, R.C.M.E., Vermulst, A.A. et al. (2013). The parent version of the Strengths and Difficulties Questionnaire: Omega as an alternative to alpha and a test for measurement invariance. European Journal of Psychological Assessment, 29(1), 44-50. http://dx.doi. European Journal of Psychological
org/10.1027/1015-5759/a000119

Tang, S., Siu, O., \& Cheung, F. (2014). A study of work-family enrichment among Chinese employees: The mediation role between work support and job satisfaction. Applied Psychology, 63(1), 130-150. http://dx.doi.org/10.1111/ j.1464-0597.2012.00519.x

Ten Brummelhuis, L.L., \& Bakker, A. (2012). A resource perspective on the work-home interface. American Psychologist, 67(7), 545-556. http://dx.doi.org/10.1037/ a0027974

Thomas, L.T., \& Ganster, C. (1995). Impact of family-supportive work variables on workfamily conflict and strain: A control perspective. Journal of Applied Psychology, 80 6-15. http://dx.doi.org/10.1037/0021-9010.80.1.6

Thompson, C., Beauvais, L, \& Lyness, K. (1999). When work-family benefits are not enough: The influence of work-family culture on benefit utilization, organizational attachment, and work-family conflict. Journal of Vocational Behaviour, 54(3), 392-415. http://dx.doi.org/10.1006/jvbe.1998.1681

Tiedje, L.B., Wortman, C.B., Downey, G., Emmons, C., Biernat, M., \& Lang, R. (1990). Women with multiple roles: Role-compatibility perceptions, satisfaction, and
mental health. Journal of Marriage and the Family, 52, 63-72. http://dx.doi. mental health. Journal
org/10.2307/352838

Van Aarde, A., \& Mostert, K. (2008). Work-home interaction of working females: What is the role of job and home characteristics? South African Journal of Industrial Psychology, 34(3), 1-10.

Van de Schoot, R., Lugtig, P., \& Hox, J. (2012). A checklist for testing measurement invariance. European Journal of Developmental Psychology, advance online publication. http://dx.doi.org/10.1080/17405629.2012.686740

Van den Berg, H., \& Van Zyl, E. (2008). A cross-cultural comparison of the stress experienced by high-level career women. South African Journal of Industrial Psychology, 34(3), 17-21.

Van Steenbergen, E.F., Ellemers, N., \& Mooijaart, A. (2007). How work and family can facilitate each other: Distinct types of work-family facilitation and outcomes for women and men. Journal of Occupational Health Psychology, 12, 279-300. http:// dx.doi.org/10.1037/1076-8998.12.3.279

Voydanoff, P. (2004). The effects of work demands and resources on work-to-family conflict and facilitation. Journal of Marriage and Family, 66, 398-412. http:// dx.doi.org/10.1111/j.1741-3737.2004.00028.x

Wadsworth, L.L., \& Owens, B.P. (2007). The effects of social support on work-family enhancement and work-family conflict in the public sector. Public Administration Review, 67(1), 75-87. http://dx.doi.org/10.1111/j.1540-6210.2006.00698.x

Wayne, J.H., Grzywacz, J.G., Carlson, D.S., \& Kacmar, K.M. (2007). Work-family facilitation: A theoretical explanation and model of primary antecedents and consequences. Human Resource Management Review, 17, 63-76. http://dx.doi. org/10.1016/j.hrmr.2007.01.002

Wayne, J.H., Randel, A.E., \&, Stevens, J. (2006). The role of identity and work-family support inwork-family enrichment and its work-related consequences. Journal of Vocational Behavior, 69, 445-461. http://dx.doi.org/10.1016/j.jvb.2006.07.002

Weer, C.H., Greenhaus, J.H., \& Linnehan, F. (2010). Commitment to nonwork roles and job performance: Enrichment and conflict perspectives. Journal of Vocationa Behavior, 76, 306-316. http://dx.doi.org/10.1016/j.jvb.2009.07.003

Winfield, I., \& Rushing, B. (2005). Bridging the border between work and family: The effects of supervisor-employee similarity. Sociological Inquiry, 75(1), 55-80 $\mathrm{http}: / / \mathrm{dx}$.doi.org/10.1111/j.1475-682X.2005.00112.x 